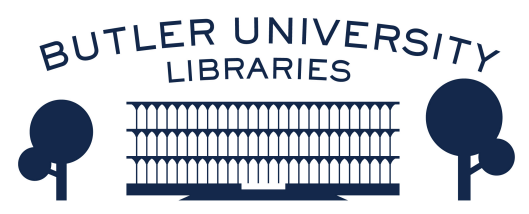

Journal of Hindu-Christian Studies

Volume 6

Article 15

January 1993

\title{
Book Review: "Salvation Outside the Church? Tracing the History of the Catholic Response"
}

Anantanand Rambachan

Follow this and additional works at: https://digitalcommons.butler.edu/jhcs

Part of the Religion Commons

\section{Recommended Citation}

Rambachan, Anantanand (1993) "Book Review: "Salvation Outside the Church? Tracing the History of the Catholic Response"," Journal of Hindu-Christian Studies: Vol. 6, Article 15.

Available at: https://doi.org/10.7825/2164-6279.1084

The Journal of Hindu-Christian Studies is a publication of the Society for Hindu-Christian Studies. The digital version is made available by Digital Commons @ Butler University. For questions about the Journal or the Society, please contact cbauman@butler.edu. For more information about Digital Commons @ Butler University, please contact digitalscholarship@butler.edu. 
and to the nature and destiny of the Self in Hinduism, Buddhism and Jainism. Step by step, logically and analytically, all variations of the larger concepts are examined to get to the meaning of karma, its truth, and its doctrinal consistency. At the end of his systematic exposition and interpretation of what has been said about the law of karma, the author attempts to put together the divergent pieces of the puzzle in a critical and constructive way.

The most creative and readable part of the book is the Epilogue. It is a rich repository of the truths and insights Reichenbach distills from this philosophical study. The values of the law of karma are cited in the objectivity of its ethics; its elevation of the principle of universal justice; its connection of actions with character; its positing of moral qualities through the notion of adrsta; its assertion that karmic actions have a cumulative effect; its championing of freedom over determinism; and most intriguing of all, its logic that a single lifetime is insufficient for the formation of the kind of character that makes liberation possible.

In a bid to reconstruct some of the deficiencies of the law of karma, Reichenbach thinks 'some sort of theistic administrator of karma is necessary' (p.189). This appears to us as an effort to Christianise the law of karma in a manner that actually mystifies the operation of justice.

The bottom line is that to write such a learned exposition of the theory of karma, the author himself must have reaped the fruit of an excellent store of prior karma; but the same cannot be said for the reviewer. There has been some dukkha mixed with sukkha. The whole book is fractured by debates within debates. The point is too often lost amid the polemics.

Cromwell Crawford, Director Centre for South Asian Studies, University of Hawaii.

\section{Salvation Outside the Church? Tracing the History of the Catholic Response. Francis A. Sullivan, S.J., New York : Paulist Press, 1992, $224 \mathrm{p}$.}

SALVATION OUTSIDE THE Church? is a historical survey of the ways in which the Catholic tradition has understood its claim that there is no salvation outside the church (extra ecclesiam nulla salus). Beginning with the reflections of some of the earliest Christian writers and concluding with papal teaching after Vatican II, Sullivan discusses the seminal theologians, Councils, movements and historical factors which have influenced Catholic interpretations of this doctrine. This work makes available a wealth of historical detail which the author skillfully musters to help us understand the changing historical realities that have, at various times, conditioned the formulation and expression of this doctrine.

Sullivan's study quite properly makes it difficult for us to discuss the extra ecclesiam nulla salus doctrine generally, without attention to its historical context, its complexities, and its exclusions. Contrary to what may be widely believed, Sullivan establishes that this doctrine was not primarily applied to those outside the boundaries of the Christian church. In fact, during the early centuries of the church it was issued as a caution towards Christians who had separated from the church by heresy or schism. Christian writers during the first three centuries were optimistic about the 
salvation of Gentiles and Jews who had lived before Christ.

With the triumph of Christianity as the official religion of the Roman empire, this doctrine was also extended as a warning to pagans and Jews. The assumption was that since the gospel had been preached to everyone in the world, those who had rejected it were guilty of grave sin and had culpably cut themselves off from the church in which salvation was possible.

The discovery of America by Columbus resulted in a collapse of the medieval worldview which equated the world with Christendom. Christianity became aware of continents inhabited by people who, through no fault of their own, had no knowledge of the gospel. A strong emphasis on the universal salvific will of God led Catholic theologians to conclude that an implicit faith in Christ is sufficient for the salvation of people 'whose lack of explicit Christian faith was inculpable'. Christian writers questioned the assumption that those who had heard and rejected the gospel were guilty of grave sin.

These trends, Sullivan points out, culminated in the statements of Vatican II on the role of the church in the salvation of nonChristians. While Vatican II recognised the salvific function of non-Catholic Christian communities, the Church still affirmed the need for non-Christians to be related to it by implicit desire. Vatican II went further than any previous Church statement in recognising in non-Christian religions 'a ray of Truth which enlightens all men' but these religions are still seen as in need of completion and fulfillment through Christianity. Non-Christian traditions are largely preparations for the gospel and Christ occupies the centre of the divine plan for salvation. It is these elements of the Catholic response with which adherents of other faiths continue to have the greatest difficulty, seeing them as expressions of a religious possessiveness which wants to appropriate and put a Christian label on all forms of genuine spirituality. While Sullivan's work is strong on history, it is not concerned with assessing the implications of the Catholic response for relationships with other faiths.

The primacy of God's will for the salvation of every human being has received great emphasis in contemporary Catholic thinking about the role and value of other religions. At the same time there is better understanding of the faith and values of those who do not follow the Christian way. While the severely limited horizons of medieval Christianity resulted in particular understandings of extra ecclesiam nulla salus, one hopes that our experience of religious diversity and friendships with people of other faiths will lead to increasingly challenging formulations and interpretations of this doctrine. Sullivan's work does in fact give us hope that we have not heard the last word on extra ecclesiam nulla salus.

Anantanand Rambachan

Department of Religion

Saint Olaf College

Northfield MN, USA 